ROCZNIKI HUMANISTYCZNE

Tom LXIX, zeszyt $6-2021$

DOI: https://doi.org/10.18290/rh21696-4

\title{
PRAWO ŚREDNIOWIECZNEJ WALII CYFRAITH HYWEL - PROLEGOMENA DO GLOSARIUSZA WALIJSKO-POLSKIEJ TERMINOLOGII PRAWNEJ
}

\begin{abstract}
WSTĘP
Prawo średniowiecznej Walii Cyfraith Hywel, zwane także prawem Hywela Dda (Hywela Dobrego od przymiotnika $d a$ - dobry, szczodry), stanowiło odrębny system prawny do XVI wieku, kiedy zostało formalnie zastąpione przez angielskie common law na mocy Aktów Unii (Acts of Union) przyjętych przez parlament angielski w 1536 i 1543 roku za rządów Henryka VIII. Przepisy prawne oparte na lokalnych, rodzimych zwyczajach i tradycjach zebrano prawdopodobnie $w$ jeden zbiór około drugiej połowy $\mathrm{X}$ wieku na zjeździe w Y Tŷ Gwyn (Biały Dom), obecnie Whitland, zwołanym - jak relacjonuje preambuła - z polecenia Hywela Dda (c. 880-949/950), króla Deheubarth, regionu południowo-zachodniej Walii. Dzieło Hywela uzupełniono w późniejszym okresie o nowe regulacje w odpowiedzi na dynamicznie zmieniające się realia polityczne i prawne, zwłaszcza penetrację pojęć i instytucji pochodzenia anglo-normańskiego. Do dnia dzisiejszego zachowały się trzy zbiory prawa (dosłownie księgi od rzeczownika llyfr - księga, książka): Llyfr Cyfnerth, Llyfr Blegywryd i Llyfr Iorwerth. Oznaczenia ksiąg pochodzą od nazwisk prawników wymienionych we wstępie: Cyfnertha ap Morgeneu,
\end{abstract}

Dr hab. KATARZYNA JAwORSKA-BiskUP - adiunkt w Instytucie Literatury i Nowych Mediów Uniwersytetu Szczecińskiego; adres do korespondencji: Uniwersytet Szczeciński, Instytut Literatury i Nowych Mediów, al. Piastów 40b, bud. 5, 71-065 Szczecin; e-mail: katarzyna.jaworska-biskup@usz.edu.pl; ORCID: https://orcid.org/0000-0001-6696-3078. 
Blegywryda Athro i Iorwertha ap Madoga. Łączna liczba rękopisów spisanych w narodowym języku walijskim i po łacinie na przełomie XIII i XV wieku wynosi czterdzieści sztuk ${ }^{1}$.

Cyfraith Hywel dzieli się na bloki tematyczne regulujące poszczególne obszary prawa. Pierwsza część, opatrzona tytułem Cyfraith y Llys (od cyfraith prawo i llys - dwór), dotyczy praw, obowiązków i kompetencji urzędników dworskich. W dalszej kolejności wyróżnić można prawo małżeńskie i rodzinne, prawo zobowiązań, prawo rzeczowe i spadkowe oraz prawo karne, występujące pod zbiorczą nazwą Cyfraith y Wlad (prawo narodu, prawo krajowe od cyfraith - prawo i gwlad - naród, państwo, grupa ludzi zamieszkująca dany obszar) (Roberts, Llawysgrif Pomffred 1-6)2 .

Dokonując krótkiej charakterystyki Cyfraith Hywel, warto nadmienić, że prawo wespół z poezją, prozą i genealogią tworzyło korpus zwany cyfarwyddyd (wiedza, doświadczenie) przekazywany w formie ustnej przez wieszczów zwanych cyfarwyddiaid (S. Davies 231-257). Najnowsze publikacje naukowe klasyfikują walijskie teksty prawne do dziedziny law as literature (prawo jako literatura), nurtu interdyscyplinarnych badań z pogranicza prawa i literatury. W monografii Law and the Imagination in Medieval Wales z 2018 roku R.C. Stacey stawia tezę, że przepisy średniowiecznego prawa walijskiego należy interpretować przez pryzmat realnych wydarzeń i postaci historycznych, w kontekście zjawisk społecznych, politycznych i kulturowych, jakie zachodziły w epoce średniowiecza w Walii, zwłaszcza kolizji rdzennych zasad prawnych $\mathrm{z}$ zasadami forsowanymi przez anglo-normańskich kolonizatorów. Według autorki Cyfraith Hywel nie jest zbiorem norm prawnych sensu stricto, ale tekstem literackim par excellence ${ }^{3}$.

\footnotetext{
${ }^{1}$ Rękopis Peniarth MS 28, datowany na ok. XIII wieku, przechowywany w Bibliotece Narodowej Walii (Llyfrgell Genedlaethol Cymru) w Aberystwyth, ozdabiają ilustracje przedstawiające króla siedzącego dostojnie na tronie, kadrę dworską, m.in. sędziego dzierżącego w dłoni księgę prawa, kucharza oporządzającego ptactwo, kowala w trakcie kucia czy zwierzęta. Przepisy dotyczące sarhaed (nawiązki) obrazuje rysunek sprawcy targającego za włosy swą ofiarę. Sekcję na temat praw kobiet otwiera wizerunek białogłowy z naczyniem w ręku (D. Huws).

${ }^{2}$ Szczegółowe informacje na temat Hywela Dda, kodyfikacji prawa, zawartości i domniemanego autorstwa ksiąg oraz datowania rękopisów zawiera strona internetowa Seminar Cyfraith Hywel dostępna pod adresem http://cyfraith-hywel.org.uk. Nie omawiam tutaj rozwoju prawa średniowiecznej Walii pod kątem wpływów i zapożyczeń z innych systemów prawnych czy uwarunkowań historycznych. Kwestii tej poświęciłam inny artykuł: Jaworska-Biskup, „Rozwój prawa średniowiecznej Walii do 1284 roku - perspektywa historyczna" 197-216.

${ }^{3} \mathrm{O}$ związkach prawa i literatury w aspekcie Walii pisała również C.F. Huws 99-120.
} 
Cyfraith Hywel wyróżnia bogata terminologia, która nie doczekała się do tej pory opracowania w języku polskim ${ }^{4}$. Niniejsze studium jest próbą komparatystyki walijsko-polskiego słownictwa prawnego w oparciu o materiały źródłowe ${ }^{5}$ i literaturę przedmiotu. Wybrane terminy wyekscerpowano z Llyfr Iorwerth pod redakcją A.R. Wiliama (Llyfr Iorwerth: A Critical Text of the Venedotian Code of Medieval Welsh Law) i angielskiego przekładu tej księgi autorstwa D. Jenkinsa (The Law of Hywel Dda: Law Texts from Medieval Wales). Llyfr Iorwerth zawiera prawo spisane w Gwynedd ok. XIII wieku za panowania Llywelyna ap Iorwertha (c. 1194-1240) i Llywelyna ap Gruffudda (1246-1282) (Roberts, Llawysgrif Pomffred 2) ${ }^{6}$.

W pracy wykorzystano także zbiór triad prawnych (Roberts, The Legal Triads of Medieval Wales). Katalogowanie informacji w postaci triad (trójek) było powszechnym zjawiskiem w kulturze celtyckiej, o czym świadczy pokaźny zasób tekstów tego typu w literaturze walijskiej i irlandzkiej (Kelly 1-18). Na wzmiankę zasługuje kolekcja Trioedd Ynys Prydein „Triady Brytanii” (dosłownie „Triady Wyspy Brytanii”) zachowana na stronach rękopisu Peniarth 16 z XIII wieku Triady mają starszą proweniencję, prawdopodobnie zostały spisane około XI i XII wieku. Tytuł zbioru sięga czasów przed najazdem plemion germańskich na Brytanię i wewnętrznym rozpadem wyspy na mniejsze ośrodki władzy. Na Trioedd Ynys Prydein składa się m.in. odrębna grupa triad nazwana Trioedd y Meirch, opisująca konie należące do postaci wchodzących w skład panteonu bohaterów narodowych, takich jak Artur. Triada zestawia obok siebie trzy wyrazy, które zwykle denotują osoby,

\footnotetext{
${ }^{4}$ Artykuł podsumowuje moje dotychczasowe badania nad prawem średniowiecznej Walii. Zbiera w całość zrewidowane ustalenia dokonane na łamach innych publikacji, anglo- i polskojęzycznych, wymienionych w bibliografii.

${ }^{5}$ Do źródeł poznania prawa walijskiego zaliczamy także literaturę fikcjonalną, prozę, poezję, kroniki i pseudo-historię. Przez pseudo-historię rozumiem autorską interpretację realnych wydarzeń historycznych opartą na istniejących mitach, legendach i podaniach. Przykładem literatury tego typu jest Historia Brittonum pseudo-Nenniusza z IX wieku i Historia Regum Britanniae Geoffrey'a z Monmouth z 1136 roku (Carey 1130-1131; P. Williams XIV). Zob. przegląd średniowiecznej literatury walijskiej w: Buczek-Zawiła 361-386; A. Majewicz i E. Majewicz 728-749. O literackich refleksjach nad prawem średniowiecznej Walii i terminologii prawnej piszę w monografii Selected Medieval Literature from Wales, Scotland and England Reflecting Changes in Welsh and Scottish Law.

${ }^{6}$ Llyfr Iorwerth nie jest jedyną księgą prawa, która zainteresowała badaczy. Wśród wielu pozycji naukowych warto przywołać edycje Llyfr Cyfnerth (Wade-Evans; Roberts, Llawysgrif Pomffred), Llyfr Blegywryd (Richards) i ksiąg po łacinie (Emanuel). A. Owen dokonał kompilacji materiału w jednym zbiorze pod tytułem Ancient Laws and Institutes of Wales opublikowanym w 1841 roku.
} 
miejsca, przedmioty i wydarzenia mające szczególne znaczenie historyczne i kulturowe. Wszystkie elementy triady są powiązane wspólnym tematem. Badacze łączą powstanie triad z kształceniem poetów. Triady pełniły przede wszystkim rolę narzędzia dydaktycznego umożliwiającego szybkie zapamiętywanie i przyswajanie materiału. Stanowiły także repozytorium tradycji i zwyczajów przekazywanych następnym pokoleniom (Bromwich, Trioedd Ynys Prydein i „The Triads of the Horses” 102-120; Wood 1896-1900). Podobna funkcję miały triady prawne. Konstruowanie przepisów prawnych w formie triad ułatwiało przywoływanie skomplikowanych reguł $\mathrm{w}$ trakcie wykładni (Roberts, „The Welsh Legal Triads” 1-22 i „The Iorwerth Triads” 155-164)

Oprócz triad teksty prawne zawierają cynghawsedd (formułowanie/wymiana argumentów $\mathrm{w}$ procesie sądowym, spór), damweiniau (przypadki, kazusy) i cwynion (skargi). Llyfr Cynghawsedd była podręcznikiem dla prawników instruującym, jak prezentować argumenty w trakcie rozprawy. Llyfr y Damweiniau to księga przypadków, sytuacji faktycznych, które mogły rodzić określone kwestie prawne. Rzeczownik cwyn oznaczał skargę wniesioną przez powoda przeciwko pozwanemu. Cwyn określała strony, stan faktyczny i roszczenie powoda. W niektórych zbiorach Cyfraith Hywel odnajdujemy wzory skarg, np. cwyn sarhaed inicjowała postępowanie w sprawie o zadośćuczynienie $\mathrm{z}$ tytułu uszczerbku na zdrowiu czy ujmy na honorze (Roberts, „Plaints in Medieval Welsh Law” 219-261 i „More Plaints in Medieval Welsh law" 171-199).

Pomocnym narzędziem w pracy nad glosariuszem okazał się słownik Geiriadur Prifysgol Cymru: A Dictionary of the Welsh Language (GPC Online). Ułożone w porządku alfabetycznym terminy opatrzono krótkim komentarzem $^{8}$. Na potrzeby analizy wyszczególniono następujące kategorie: nazwy urzędów dworskich, terminologia prawa rodzinnego i małżeńskiego, nazwy czynów zabronionych, terminologia zobowiązań umownych i deliktowych,

\footnotetext{
${ }^{7}$ Niektóre triady wykraczają poza kontekst prawa. W bogatym ilościowo korpusie triad istnieje wiele fragmentów, które wyrażają pewne uniwersalne prawdy życiowe. Na przykład jedna z triad wysławia zasadę, że zaprzeczeniem mądrości jest pijaństwo, cudzołóstwo i porywczy charakter (Roberts, The Legal Triads of Medieval Wales 89).

${ }^{8}$ Przy doborze polskich ekwiwalentów sugerowałam się staropolską terminologią prawa szczegółowo omówioną w pracach czołowych językoznawców i historyków prawa (A. Zajdy, M. Lizisowej, J. Rafacza, S. Kutrzeby, J. Bardacha, Z. Góralskiego, M. Koczerskiej i A. Lisa). Znaczenie wielu terminów prawnych objaśniają także cytowane słowniki i encyklopedie. Lista pozycji dotyczących średniowiecznego prawa polskiego i słownictwa prawnego znajduje się w bibliografii. Nie wszystkie walijskie nazwy mają swoje polskie odpowiedniki. W sytuacji braku korespondencji pomiędzy terminem źródłowym a docelowym podano znaczenie opisowe.
} 
terminologia prawa rzeczowego i spadkowego oraz terminy postępowania sądowego. Zebrany materiał wskazuje na dużą liczbę derywatów, złożeń i zrostów, co uzasadnia potrzebę rozbioru niektórych terminów na mniejsze jednostki leksykalne celem ilustracji ich znaczenia. Pełna analiza słowotwórcza terminologii prawnej wykracza poza ramy tej pracy. Wypada jedynie zasygnalizować, że wysoka frekwencja compositów nie jest cechą wyłącznie średniowiecznego walijskiego języka prawa. Podobne zjawisko można zaobserwować w tekstach użytkowych i artystycznych, zwłaszcza w poezji walijskiej (Heinz, „Walisisch” 300) .

\section{URZĘDY I GODNOŚCI DWORSKIE}

Nazwy urzędów dworskich pochodzą z działu Cyfraith Hywel w całości poświęconego strukturze i organizacji dworu królewskiego (llys). Katalog dygnitarzy skupionych wokół króla (brenin) obejmował następujących urzędników:

- Bardd Teulu (bard, nadworny poeta),

- Brawdwr Llys/Ynad Llys (sędzia nadworny),

- Canhwyllydd (zapalający świece),

- Cog (kucharz),

- Distain (kuchmistrz),

- Drysor/Drysor Neuadd (strażnik),

- Gostegwr (porządkowy),

- Gwas Ystafell (podkomorzy),

- Meddydd (wytwórca meddu, piwniczy) ${ }^{10}$,

- Meddyg (medyk),

- Offeiriad/Offeiriad Teulu (kapelan, duchowny),

${ }^{9}$ Szerzej na temat słowotwórstwa walijskiego zob. Heinz, Welsh Fictionaries in the Twentieth Century: A Critical Analysis.

${ }^{10}$ Spożywanie miodu było nieodłącznym elementem życia dworskiego. Literatura walijska obfituje we fragmenty odnoszące się bezpośrednio do tego trunku. Miód pełnił również funkcje symboliczne, zwłaszcza w poezji. O miodzie wzmiankuje m.in. Y Gododdin, jedno z najstarszych zachowanych źródeł literackich, datowane na ok. VI/VII wiek. Zanim oddział zbrojny plemienia Gododdin wyruszył na militarną ekspedycję przeciwko Anglom do Catraeth spędził okrągły rok w Din Eidyn (obecnie Edynburg) na wspólnym biesiadowaniu. Ważnym ceremoniałem podczas ucztowania było picie miodu (G. Williams 17-19). Specjalne zasady prawne zawarte w Cyfraith Hywel przewidywały sankcje za zabór roju pszczelego i określały uprawnienia właścicielskie do pszczół (Jenkins, The Law of Hywel Dda). Eksploracja tego frapującego zagadnienia badawczego wykracza poza wąskie ramy tej pracy. 
- Pencynydd (główny łowczy) $)^{11}$,

- Pengwastrawd (główny koniuszy),

- Penhebogydd (główny sokolnik),

- Penteulu (dowódca drużyny),

- Trulliad (podczaszy).

Niektóre z wyżej wymienionych osób wykonywały obowiązki względem małżonki króla (brenhines). Służba królowej obejmowała takich urzędników, jak Canhwyllydd, Cog, Distain, Drysor, znany także pod nazwą Drysor Ystafell (strażnik komnaty), Gwas Ystafell, Offeiriad, Pengwastrawd. Do obsługi królowej powołana była również Llawforwyn y Frenhines/Morwyn Ystafell (służka). Bazując na etymologii wyrazu desygnującego ten urząd (llaw - ręka i morwyn - kobieta), można wywieść, że kobieta go sprawująca wykonywała prace fizyczne, przede wszystkim związane z komnatą (llawforwyn, GPC Online). Posługę na dworze pełniły także inne osoby, a mianowicie:

- Cynutai (sprawujący nadzór nad ogniem),

- Gof Llys (kowal),

- Golchuries (praczka),

- Gwastrawd (stajenny),

- Gwyliwr (stróż, wartownik),

- Maer Biswail (zarządca ziemią przylegającą do dworu zwaną maerdref, która zaopatrywała dwór w żywność, poborca opłat),

- Pencerdd (bard główny, arcybard),

- Poburies (służka zajmująca się wypiekiem chleba),

- Porthor (odźwierny),

- Rhingyll (oficer w drużynie królewskiej, strażnik, poborca opłat odprowadzanych do królewskiego skarbca),

- Troediog (trzymający i masujący stopy króla) ${ }^{12}$.

Dwór składał się z rodziny królewskiej, która obejmowała brenina (króla), brenhines (małżonkę króla) i edlinga (następcę tronu), urzędników głównych oraz dodatkowy personel. Zanim przystąpimy do przeglądu najważniejszych urzędników dworskich należy naświetlić kwestię nazewnictwa osób sprawu-

${ }^{11}$ Nazwy od litery $l$ do $o$ poprzedza przedrostek pen, który oznacza głowę, szczyt, kierownika, przywódcę, lidera (pen, GPC Online). Wymienione wyżej osoby sprawowały zatem funkcje nadzorcze nad podległą służbą. Tłumacząc literalnie, chodzi o głównego/naczelnego łowczego, koniuszego, sokolnika i dowódcę drużyny.

${ }^{12}$ Listę sporządzono na podstawie: Wiliam 1-22; Jenkins, The Law of Hywel Dda 5-39 i „Prolegomena to the Welsh Laws of Court” 19; Góralski 130-153; Zajda, Nazwy urzędników staropolskich (do roku 1600). 
jących władzę zwierzchnią w średniowiecznej Walii. Redaktorzy Llyfr Iorwerth posługują się terminem brenin (król). Walia nie była jednak jednolitym państwem zarządzanym przez królów, jak mogłoby się wydawać z lektury tego źródła, a zespołem mniejszych, niezależnych królestw, na czele których stali książęta, w języku walijskim tywysogion (lp. tywysog) ${ }^{13}$. Zjednoczona Walia pozostawała pod panowaniem jednego władcy, Gruffudda ap Llywelyna, w latach 1055-1063. W tekstach prawnych występuje także termin arglwydd (pan, opiekun, patron) ${ }^{14}$. W aspekcie stosunków feudalnych arglwydd odnosił się do zwierzchnika, pana feudalnego na danym terenie. Podległy mu wasal był obowiązany składać do jego kasy podatki, daniny, kary finansowe przewidziane za pewne typy przewinień i opłatę amobr z okazji zawieranego małżeństwa, o czym mowa niżej. W prawie rodzinnym mianem arglwydda określano męża względem żony (Jenkins, „Kings, Lords, and Princes” 451-462).

Każdy z wyżej wymienionych urzędników wykonywał określone obowiązki. Penteulu (dowódca) przewodził drużynie (teulu), zawiadywał wojskiem na polu bitwy, asystował królowi podczas objazdu (cylch). Na penteulu desygnowano osobę z najbliższego otoczenia króla, zwykle syna, bratanka lub dostojnika wysokiej rangi cieszącego się zaufaniem monarchy. Rzeczownik penteulu wywodzi się od wyrazów pen - głowa i teulu - rodzina, co w dosłownym przekładzie znaczy głowa rodziny (penteulu, GPC Online). Poza penteulu jednym $\mathrm{z}$ niezastąpionych urzędników królewskich był offeiriad (kapelan, duchowny, kaznodzieja), do którego zadań należały rytuały liturgiczne, jak odprawianie mszy czy błogosławienie jedzenia przy akompaniamencie pacierza, oraz czynności kancelaryjne i notarialne, przede wszystkim sprawowanie pieczy nad dokumentacją, sporządzanie i odczytywanie korespondencji (Pryce, „The Household Priest” 82-93). Głównym obowiązkiem meddyga (nadwornego lekarza) było świadczenie usług medycznych zarówno we dworze, jak i na polu bitwy oraz doradztwo w sprawie diety (Owen 116-141). Distain, termin zbliżony do polskiego kuchmistrza, zajmował się nadzorem nad kuchnią poprzez między innymi kontrolę posiłków i trunków serwowanych na stole. Gwas Ystafell, którego odpowiednikiem w języku polskim jest

${ }^{13} \mathrm{~W}$ dalszej części pracy używam pojęcia król zgodnie z konwencją zastosowaną w tekstach prawnych.

${ }^{14}$ Poeci walijscy często używali wyrazu arglwydd wówczas, gdy odnosili się do Boga jako najwyższego stwórcy. Jednym z wyrazów kultu maryjnego w Walii było nazywanie Maryi arglwyddes (Arglwyddes Fair). Arglwydd w kontekście religijnym jest nadal używany we współczesnym języku walijskim. Wyraz ten także funkcjonuje w sferze administracyjnej, czego przykładem jest zwrot Arglwydd Faer (burmistrz) (arglwydd, GPC Online). 
podkomorzy lub mający francuską proweniencję szambelan, troszczył się o komnatę królewską. Za swoją posługę otrzymywał stare, zużyte tkaniny przykrywające łoże królewskie. Termin ten powstał z połączenia wyrazów gwas - urzędnik, służący i ystafell - pokój, komnata, komora. Meddydd produkował medd, rodzaj alkoholu na bazie miodu i wody z dodatkiem przypraw, ulubionego napoju ówczesnej elity. Trulliad dbał o wyposażenie spiżarni, wydawał trunki na stół i wlewał je do kielichów. Zakres obowiązków tego urzędnika czyni go podobnym do staropolskiego podczaszego. Drysor (strażnik) strzegł wejścia do głównej hali. Gostegwr (od czasownika gostegu uciszać, uspokajać) nawoływał do zachowania porządku i ciszy. Cog (kucharz) przygotowywał strawę, smakując osobiście dań podawanych rodzinie królewskiej i zgromadzonym gościom. Canhwyllydd trzymał świecę (cannwyll) podczas spożywania posiłków przez króla, oświetlał królowi przejście do komnaty, zapalał i gasił świece. Pengwastrawd (koniuszy) dbał o stajnie dworskie i przychówek królewski.

Wymiar sprawiedliwości należał do brawdwr llys (sędziego nadwornego od rzeczownika brawd - wyrok; brawdwr - wydający wyrok) $)^{15}$. W zbiorze Cyfraith Hywel sędzia nadworny określany jest także terminem ynad llys, a w wersji prawa sporządzonej po łacinie, iudex curie. W Cyfraith y Wlad pojawia się termin ynad (dosłownie znający prawo). Ynad miał zapewne znaczenie szersze niż brawdwr/ynad llys i oznaczał pierwotnie jurystę, uczonego w prawie. W księdze Llyfr Prawf Ynaid, będącej podręcznikiem dla adeptów zawodu sędziowskiego (od prawf-egzamin, test), ynad opisuje sędziego, który zdobył edukację prawniczą, złożył egzamin przed brawdwr llys i został oficjalnie dopuszczony do orzekania. Wymogiem piastowania stanowiska sędziowskiego było opanowanie Tair Colofn Cyfraith („Trzy Filary Prawa"), o których szerzej traktuje dalsza część opracowania, oraz Gwerth Gwyllt a Dof (wartość zwierząt, tych domowych i tych dzikich, niezbędna do wyliczania odszkodowania $\mathrm{z}$ tytułu zobowiązań deliktowych) (Smith, „Ynad Llys, Brawdwr Llys, Iudex Curie” 94-115 i „Judgement under the Law of Wales" 63-103). Ynad szczycił się nie tylko biegłością w meandrach prawa, ale także znajomością prozy, poezji i pseudo-historii (Elias i Owen 112). Dla każdego okręgu cwmwd ustanawiano ynad cwmwd,

${ }^{15}$ Brawd w języku walijskim ma szerokie znaczenie. Wyraz ten desygnuje brata, współtowarzysza, brata zakonnika. W kontekście prawnym brawd odnosi się do wyroku, decyzji wydanej przez sędziego. Geiriadur Prifysgol Cymru notuje także zwrot brawd llys jako wyrok sądowy (brawd, GPC Online). 
lokalnego mediatora i rozjemcę rozstrzygającego sprawy zawisłe na danym terenie (Davies, „The Administration of Law in Medieval Wales” 258-273). W Walii praktykowali także prawnicy zwani dosbarthwyr (od dosbarth wyrok, rozum, wiedza, mądrość ${ }^{16}$. Dosbarthwr był koncyliatorem, arbitrem między zwaśnionymi stronami oraz ekspertem prawa powoływanym do rozstrzygania kwestii spornych i kolizji przepisów prawa (James 157).

Omawiając funkcjonowanie dworu w średniowiecznej Walii, nie można pominąć bardów, których rola polegała przede wszystkim na zabawianiu członków dworu i przybyłych na wspólne ucztowanie biesiadników. Bardowie byli także strażnikami tradycji, prawa i literatury. W Llyfr Iorwerth odnaleźć można wzmiankę o dwóch rodzajach tego urzędu, a mianowicie bardd teulu i pencerdd. Bardd teulu (dosłownie bard rodziny od rzeczownika teulu - rodzina) pozostawał do dyspozycji króla we dworze, prezentując swoje umiejętności artystyczne. Było to stanowisko ściśle związane z dworem panującego, a dokładnie jego rodziną. Bardd teulu towarzyszył również drużynie na polu bitwy, zagrzewając ją do walki ${ }^{17}$. Pencerdd był członkiem zrzeszenia bardów, które skupiało piastunów tego zaszczytnego zawodu oraz uczniów pobierających naukę od mistrzów. W nawiązaniu do etymologii pencerdda (pen - głowa, cerdd - pieśń, wiersz, cerddoriaeth - muzyka) w literaturze jest on zwykle nazywany głównym, naczelnym poetą, wyższym w hierarchii od bardd teulu (pencerdd, GPC Online; Jenkins, „Bardd Teulu and Pencerdd” 142-166).

Dodatkowy personel dworski stanowił troediog (od troed - stopa), który ogrzewał i masował stopy królewskie. Rhingyll był oficerem odpowiedzialnym za pilnowanie porządku we dworze, pobór opłat i danin należnych królowi, m.in. gwestfa (stancja, gościna od gwest - nocleg, kwaterunek i mamiejsce) (gwestfa, GPC Online). Współcześnie rzeczownik ten oznacza funkcjonariusza w szeregach policji lub armii (rhingyll, GPC Online). Codzienne funkcjonowanie dworu zabezpieczały takie osoby, jak cynutai (strzegący ognia, głównego źródła ciepła i światła), poburies (kobieta wypiekająca chleb), gof llys (kowal) i golchuries (praczka). Obok wspomnianego

\footnotetext{
${ }^{16}$ Poza sferą prawa dosbarth oznacza klasę w znaczeniu grupy osób pobierających naukę, zajęcia, formularz (dosbarth, GPC Online).

${ }^{17} \mathrm{O}$ ważkiej roli barda w kulturze walijskiej świadczy Eisteddfod, narodowy festiwal poezji i muzyki. Prototypem współczesnego Eisteddfodu był Eisteddfod zorganizowany w roku 1176 w Cardigan przez Rhysa ap Gruffudd, władcy Deheubarth, znanego jako Lord Rhys. Więcej na ten temat: Rosiak 155-165.
} 
wyżej drysora, nad bezpieczeństwem króla i jego rodziny oraz pozostałych osób czuwali porthor i gwyliwr. Porthor (odźwierny) stał na straży u wrót prowadzących do dworu. Gwyliwr (stróż) sprawował wartę nocą (gwylio obserwować, pilnować), gdy cała świta udała się na spoczynek.

Każdy z wymienionych urzędników mógł udzielić osobie szukającej schronienia przed odpowiedzialnością karną specjalnej opieki zwanej nawdd. Termin nawdd, tłumaczony dosłownie jako mir, azyl, ochrona, określał przestrzenny i czasowy zakres ochrony uzależniony od stanu opiekuna (braint). W opinii H. Pryce'a, instytucja nawdd była prototypem azylu kościelnego. Pojęcie noddfa, przekładając literalnie na język polski, miejsce ochrony (od nawdd - ochrona, opieka i $m a$ - miejsce), desygnowało obszar (zwykle wewnątrz świątyni i w jej obrębie) objęty azylem i immunitetem (Pryce, Native Law and the Church in Medieval Wales 165-174; Davies, „Adding Insult to Injury” 137-164).

\section{TERMINOLOGIA PRAWA RODZINNEGO I MAŁŻEŃSKIEGO}

Cyfraith y Wlad otwiera grupa przepisów składająca się na Cyfraith Gwragedd, w języku polskim prawo kobiet (od cyfraith - prawo i gwragedd kobiety, liczba mnoga od rzeczownika gwraig), dedykowana małżeństwu i rodzinie. Na bazie tego materiału zebrano następujące terminy (Wiliam 24-32; Jenkins, The Law of Hywel Dda 45-61) ${ }^{18}$ :

- agweddi (wiano, wkład wnoszony do małżeństwa przez mężczyznę, związek małżeński o stażu krótszym niż okres siedmioletni),

- amobr (opłata $\mathrm{z}$ okazji zawarcia związku małżeńskiego składana zwierzchnikowi feudalnemu),

- argyfrau/argyfreu (wyprawa, szczebrzuch, przedmioty użytku osobistego, ruchomości, które kobieta wnosiła do małżeństwa),

- caradas (związek nieformalny, przygodny),

- cowyll (podarek poranny z okazji nocy poślubnej stanowiący zapłatę za utracone dziewictwo),

${ }^{18}$ Szczegółową charakterystykę średniowiecznego walijskiego prawa małżeńskiego przedstawia monografia: Jenkins i Owen, The Welsh Law of Women. Pierwszą próbę opracowania tego zagadnienia w języku polskim podjęłam w artykule: „Małżeństwo i rozwód w średniowiecznym prawie Hywel Dda (Cyfraith Hywel)” 241-253. O polskim małżeństwie doby wieków średnich traktuje pozycja: Koczerska, Rodzina szlachecka w Polsce późnego średniowiecza. Z nowszych publikacji na temat prawa polskiego zob. Lis, Family Law of the Piast Poland. 
- gwaddol (posag, wkład wnoszony do małżeństwa przez rodzinę panny młodej),

- llathrudd (wspólne zamieszkiwanie kobiety z mężczyzną),

- priodas (małżeństwo, związek małżeński o stażu powyżej siedmiu lat),

- rhodd cenedl (przekazanie kobiety mężczyźnie przez jej krewnych),

- ysgar (separacja, rozwód).

Według Cyfraith Hywel związek małżeński powstawał w wyniku rhodd cenedl. Rhodd cenedl oznacza dosłownie podarunek od krewnych (od rhodddar, podarunek i cenedl - krewni) (rhodd cenedl, GPC Online). Istotą rhodd cenedl było zawarcie umowy pomiędzy mężczyzną a krewnymi kobiety (zmówiny). Zawarty układ formalnie regulował zasady przekazania opieki przez rodzinę panny. Wgląd w Cyfraith Gwragedd pozwala wysunąć wniosek, że częścią zaślubin były zdawiny, które obejmowały wprowadzenie panny do łożnicy w celu konsumpcji związku w obecności neithiorwyr (gości weselnych). Rzeczownik neithiorwyr wywodzi się od wyrazu neithior, który oznacza ucztę weselną (neithiorwyr, GPC Online). Terminu llathrudd używano na opis wspólnego współżycia z pominięciem procedury rhodd cenedl. Dochodziło do niego najczęściej poprzez ucieczkę pary lub uprowadzenie kobiety. Co ważne, dla uznania związku za llathrudd wymagano zgody obojga partnerów (llathrudd, GPC Online). Po siedmiu latach zamieszkiwania pod jednym dachem llathrudd przekształcał się w prawowite małżeństwo. W literaturze przedmiotu autorzy czynią wzmiankę o terminie mającym zbliżone znaczenie do llathrudd zwanym caradas. Według Geiriadur Prifysgol Cymru synonimem caradas jest konkubinat (caradas, GPC Online). C. McAll tłumaczy caradas jako „związek potajemny, niedozwolony” (,illicit affair”) (McAll 16). Zdaniem T.M. Charlesa-Edwardsa caradas stosowano na opis związku polegającego na stałych, przygodnych stosunkach mężczyzny i kobiety. W odróżnieniu od llathrudd kobieta pozostawała w domu rodzinnym. Jak dodaje autor, relacja damsko-męska tego rodzaju była często aprobowana przez krewnych i najbliższe otoczenie kobiety. Analogicznie jak w przypadku llathrudd okres siedmioletni powodował przekształcenie caradas ex lege w małżeństwo (Charles-Edwards, „Naw Kynywedi Teithiauc”30).

W walijskim prawie rodzinnym, podobnie jak w prawie staropolskim, zawarciu małżeństwa towarzyszyło przekazanie określonych składników majątkowych przez zarówno krewnych panny, jak i pana młodego. Mężczyzna wnosił do związku agweddi, odpowiednik polskiego wiana. Ojciec lub opiekun panny młodej z kolei przekazywał nupturientom posag o nazwie gwaddol. Ekwiwalentem polskiej wyprawy, obejmującej przedmioty codziennego użytku 
takie jak ubrania, biżuteria i meble, jest w prawie walijskim termin argyfrau. Warunkiem koniecznym ważności małżeństwa były pokładziny. Z okazji nocy poślubnej mąż wręczał żonie cowyll, podarek poranny (Watkin 55).

Istotne z punktu widzenia podziału wspólnego majątku w przypadku rozwiązania małżeństwa (ysgar) było rozgraniczenie na agweddi i priodas. Agweddi miało podwójne znaczenie. Obok wiana termin ten opisywał związek o stażu krótszym niż siedem lat. Po upływie okresu siedmioletniego małżeństwo przekształcało się w priodas. Priodas pochodzi od przymiotnika priod. W kontekście prawa małżeńskiego priod oznacza osobę zamężną. W znaczeniu przymiotnikowym priod desygnuje atrybut prawidłowości, zgodności z prawem, legalności. W tym sensie interesujące nas priodas konotuje związek uznany przez prawo. Priod opisuje również właściciela (priod, GPC Online). Trudno odmówić racji C. McAllowi, który dostrzega jaskrawą paralelę między uprawnieniami właścicielskimi wynikającymi z prawa rzeczowego a statusem prawnym małżonków złączonych więzami priodas. Upływ okresu siedmioletniego inaugurującego priodas wywoływał skutki prawne w zakresie wspólnej własności małżeńskiej. Parze związanej priodas przysługiwały równe prawa do wspólnego majątku (McAll 16). Zgodnie z jednym z wyimków Cyfraith Hywel jedynie kobieta, która była priod mogła dokonywać sprzedaży i kupna ruchomości (Wiliam 30; Jenkins, The Law of Hywel Dda 58). Na tej podstawie można stwierdzić, że cieszyła się większymi przywilejami niż jej odpowiedniczki żyjące w relacjach innych niż priodas. Jeżeli do rozpadu związku dochodziło na mocy obopólnej zgody małżonków lub $\mathrm{z}$ wyłącznej winy męża $\mathrm{w}$ trakcie biegu terminu siedmioletniego, kobieta zatrzymywała agweddi, argyfrau i cowyll. Związek o stażu powyżej siedmiu lat zwany priodas regulowały przepisy, które precyzyjnie określały podział majątku. Podziałowi podlegały przedmioty ruchome takie, jak naczynia, ubrania, pościel, żywność i zwierzęta domowe. Zbiór Cyfraith Hywel określał także zakres sprawowania władzy rodzicielskiej nad wspólnym potomstwem i odpowiedzialność za zobowiązania finansowe. Prawo rozwiązania małżeństwa należało zarówno do kobiety, jak i mężczyzny. Według Cyfraith Hywel kobieta mogła opuścić męża i związać się z innym partnerem. Wypłata agweddi zależała wówczas od okoliczności rozstania. W myśl prawa kobieta zatrzymywała agweddi, gdy rozstanie nastąpiło na skutek problemów zdrowotnych męża, a dokładnie trądu, impotencji i nieświeżego oddechu. Agweddi było zatem pewną formą rekompensaty i zabezpieczenia interesów majątkowych kobiety. Odtrącenie męża przez żonę z obejściem wymienionych wyżej przesłanek niosło ze sobą przepadek wszystkich składników majątkowych z wyjątkiem cowyll, argyfrau i wynebwerth. Termin 
wynebwerth, o którym mowa w dalszej części pracy, oznaczał nawiązkę za zniesławienie (Jenkins, The Law of Hywel Dda 45-46; Roberts, „Emerging from the Bushes" 63 i The Legal Triads of Medieval Wales 43).

Jednym z refleksów stosunków feudalnych w prawie walijskim było pojęcie amobr, używane na opis specjalnej opłaty pobieranej przez zwierzchnika feudalnego. Opłata była uiszczana przez krewnych panny młodej, pana młodego lub samą kobietę. Kobieta płaciła amobr, jeśli współżyła z mężczyzną bez zgody krewnych lub wbrew ich woli. Wysokość amobr odpowiadała stanowi płatnika (Wiliam 29; Jenkins, The Law of Hywel Dda 49-50). Na prawach dygresji warto nadmienić, że instytucja amobr nie została zniesiona przez Edwarda I po podboju Księstwa Walii (Principality of Wales) w 1283 roku i uchwaleniu Ustawy z Rhuddlan (Statute of Rhuddlan) w 1284 roku. Dla angielskiego najeźdźcy stała się narzędziem eksploatacji mieszkańców Walii, zwłaszcza opresji kobiet. Amobr egzekwował specjalnie do tego powołany urzędnik zwany amobrwr. Zwolnieniu z opłaty podlegały jedynie kobiety pochodzenia angielskiego lub których ojcowie byli w posiadaniu ziemi należącej do angielskiego monarchy (Johnson 10-21; Davies, „The Status of Women" 103-105).

Analizując Cyfraith Hywel, nie sposób nie dostrzec wyraźnej różnicy między pojęciami gwraig i morwyn. W języku walijskim gwraig oznacza zarówno kobietę dorosłą, jak i żonę (gwraig, GPC Online ). Morwyn z kolei desygnuje kobietę, która nie zakończyła okresu dojrzewania, w potocznym języku dziewczynkę lub pannę (morwyn, GPC Online). W średniowiecznych tekstach prawnych rozgraniczenie między gwraig i morwyn zasadzało się na fakcie podjęcia współżycia płciowego. Terminem gwraig opisywano kobietę, która rozpoczęła obcowanie cielesne. Za pomocą twyllforwyn definiowano tak zwaną fałszywą dziewicę (od twyll - oszustwo, fałszerstwo, twyllo - oszukać, zwodzić, wprowadzać w błąd), dziewczynę, która w trakcie pokładzin nie zdołała udowodnić czystości (twyllforwyn, GPC Online). Pod zwrotem gwraig llwyn a pherth kryła się kobieta nakryta in flagranti $\mathrm{w}$ trakcie lub bezpośrednio po odbyciu stosunku seksualnego. Opierając się na definicji zaczerpniętej z Geiriadur Prifysgol Cymru, gwraig llwyn a pherth, oznacza kurtyzanę, ladacznicę, cudzołożnicę, kobietę uprawiającą nierząd. Zwrot pochodzi od wyrazów gwraig (kobieta) i llwyn/pherth (krzaki, zarośla). Jeśli gwraig llwyn a pherth powiła syna, otrzymywał on status mab llwyn a pherth (gwraig llwyn a pherth, GPC Online). 


\section{NAZWY CZYNÓW ZABRONIONYCH}

Do kolejnej kategorii walijskiego słownictwa prawnego należy terminologia z zakresu prawa deliktów i prawa karnego. Cyfraith Hywel wymienia następujące nazwy czynów zabronionych ${ }^{19}$ :

- anghyfarch (zabór cudzego mienia bez zamiaru przywłaszczenia),

- ffyrnigrwydd (uszkodzenie mienia),

- galanas (mężobójstwo),

- lladrad (kradzież, zabór cudzego mienia w celu przywłaszczenia),

- lladrad angynharchawl (kradzież ukryta, niejawna),

- lladrad cynharchawl (kradzież jawna, oczywista),

- tân (podpalenie),

- trais (przemoc, rozbój, kradzież rozbójnicza, gwałt).

Cyfraith Hywel wprowadzało pojęcie Tair Colofn Cyfraith, tzw. „Trzech Kolumn (Filarów, Fundamentów) Prawa”. „Kolumny Prawa” obejmowały odpowiednio galanas (mężobójstwo), lladrad (kradzież) i tân (podpalenie). Obok czynu głównego istniało dodatkowo dziewięć affaith (formy zjawiskowe), które można sprowadzić do współsprawstwa, pomocnictwa, podżegania i poplecznictwa. W odróżnieniu od Tair Colofn Cyfraith, za które pryncypał płacił odszkodowanie lub podlegał określonej karze, affaith sankcjonowano pokupem dirwy należnym arglwyddowi (Wiliam 69-70; Jenkins, The Law of Hywel Dda 143).

Pierwszą „kolumną prawa” było galanas (mężobójstwo). Termin galanas oznaczał, oprócz mężobójstwa i główszczyzny, wróżdę między rodem ofiary a rodem mężobójcy (galanas, GPC Online). Aby pociągnąć sprawcę do odpowiedzialności za galanas, wymagano zamiaru popełnienia czynu. Istniały jednak wyjątki od tej reguły, czego przykładem jest przepis dotyczący wykonywania nadzoru nad bronią. Prawo stanowiło, że jeśli doszło do popełnienia czynu zabronionego przy użyciu broni pozostawionej bez opieki, w wypłacie główszczyzny uczestniczył wraz ze sprawcą jej właściciel (Jenkins, The Law of Hywel Dda 151). Za mężobójstwo prawo walijskie przewidywało odpowiedzialność zbiorową. Rodzina ofiary występowała $\mathrm{z}$ roszczeniem o odpowiednią sumę galanas (główszczyzna), wyliczaną zgodnie z zasadami określonymi $\mathrm{w}$ zbiorze, przeciwko winnemu i jego krewnym, rodzicom

\footnotetext{
${ }^{19}$ Pogłębione studium na temat Tair Colofn Cyfraith i terminologii związanej z tym wycinkiem prawa wraz z angielskim przekładem przedstawia monografia: Charles-Edwards i Russell, Tair Colofn Cyfraith: The Three Columns of Law in Medieval Wales: Homicide, Theft and Fire.
} 
i rodzeństwu. W sytuacji, gdy sprawca uchybił wypłacie odszkodowania, najbliższym denata przysługiwało prawo krwawej zemsty. Pewne rodzaje zabójstw były wyłączone $\mathrm{z}$ katalogu czynów objętych nakazem finansowej rekompensaty. Zadośćuczynieniu nie podlegało pozbawienie życia nałożnicy męża przez żonę w momencie wzburzenia emocjonalnego, zdrajcy, wygnańca czy osób ujętych nocą w komnacie króla. Przesłanką niweczącą syngularną odpowiedzialność sprawcy był również wiek (lata sprawne określano na 14. rok życia mężczyzny i 12. kobiety) oraz upośledzenie fizyczne i umysłowe. Za niektóre czyny przewidywano wyższą galanas. Surowiej karano skrytobójstwo (cynllwyn), otrucie, zabójstwo popełnione z premedytacją i z pobudek zasługujących na szczególne potępienie. Na poczet główszczyzny płatnicy mogli dokonać alienacji ziemi. Grunt przeznaczony na zaspokojenie zaległego zobowiązania nazywano gwaetir $^{20}$ (krwawy grunt, grunt splamiony krwią od gwaed - krew i tir - grunt, ziemia) (gwaetir, GPC Online; Wiliam 69-76; Jenkins, The Law of Hywel Dda 143-153; Watkin 65-67).

Kolejną „kolumną prawa” była lladrad (kradzież). Cyfraith Hywel wyróżniało dwa rodzaje kradzieży ${ }^{21}$. Wówczas, gdy zaboru rzeczy dokonano jawnie i sprawca został zatrzymany lub pochwycony na gorącym uczynku (lladrad yn llaw - złapany za rękę od llaw - ręka), czyn wypełniał znamiona lladrad cynharchawl (kradzież jawna, oczywista). Odpowiedzialność karną warunkowała wartość skradzionego przedmiotu. Kradzież mienia powyżej 4 pensów skutkowała karą śmierci. Sprawca kradzieży przedmiotu poniżej tej sumy mógł wykupić się od kary pod warunkiem, że zapłacił opłatę wykupną gwerth stanowiącą 7 funtów. Sprawcę tego rodzaju nazywano lleidr gwerth (od lleidr - sprawca kradzieży, potocznie złodziej i gwerth - wartość). Nieuiszczenie wymaganej opłaty dawało podstawę do zastosowania innego środka karnego, banicji. Drugą formą kradzieży była lladrad angynharchawl (kradzież ukryta). Sprawca lladrad angynharchawl zwalniał się od odpowiedzialności prawnej, jeśli zdołał poprzeć składane zeznanie odpowiednią

${ }^{20}$ Nazwa gwaetir przywodzi na myśl biblijne krwawe pole zakupione za srebrniki Judasza wręczone mu za zdradę Jezusa (Mt 27,5-6; Dz 1,16-20). Historycy prawa twierdzą, że wiele przepisów Cyfraith Hywel ma swój rodowód w Biblii (Watkin 42-43). Nie można wykluczyć, że regulacje związane z galanas, w tym pojęcie krwawego gruntu, nawiązują do Pisma Świętego. Zob. Jaworska-Biskup, „Some Remarks on the Periodisation of Welsh Medieval Law” 56-57.

${ }^{21}$ Podziały kradzieży na typy zarówno ze względu na rodzaj i charakter dokonanego czynu, jak i grożące sankcje karne istniały w prawie polskim, by wymienić tylko kradzież wielką i małą w prawie ziemi łęczyckiej XIV i XV wieku czy chąśbę/chążbę, kradzież potajemną, popełnioną nocą (Rafacz, „Kradzież w prawie łęczyckiem XIV i XV wieku” 33-45; Ślaski 8-9). 
liczbą świadków i współprzysiężników (Wiliam 74-80; Jenkins, The Law of Hywel Dda 156-169; Watkin 67-69).

Kradzież odróżniano od innych czynów zabronionych, takich jak anghyfarch i trais. Anghyfarch polegał na zaborze cudzej rzeczy bez uprzedniej zgody właściciela, dosłownie tłumacząc bez pytania (cyfrach - pytać, prosić). W przeciwieństwie do lladrad sprawcą nie kierował zamiar przywłaszczenia przedmiotu. Kradzieży nie popełniała także osoba, która dokonała zaboru mienia przez pomyłkę (anoddau). Jeśli do przywłaszczenia dochodziło w wyniku przemocy, czyn taki kwalifikowano jako trais (rozbój, napad, kradzież rozbójnicza) (Jenkins, „Towards the Jury in Medieval Wales” 35; Watkin 67-68). Obok wskazanych typów czynów zabronionych skierowanych przeciwko mieniu, w Cyfraith Hywel odnotować można także akt zniszczenia cudzego mienia nazywany ffyrnigrwydd (Jenkins, „Towards the Jury in Medieval Wales" 35). Czyn ten był dokonywany przy użyciu siły i przemocy, na co wskazuje słownikowy opis rzeczownika ffyrnigrwydd jako desygnatu aktu furii, złości i przemocy (ffyrnigrwydd, GPC Online).

Triadę „kolumn prawa” dopełniał występek zwany tân (ogień), który w języku polskim tłumaczymy jako podpalenie. Winny podpalenia, podobnie jak sprawca galanas, miał obowiązek finansowej rekompensaty za poniesione szkody właścicielowi uszkodzonego budynku. W zbiorze znajdują się liczne przepisy o charakterze prewencyjnym. Prawo nakładało sankcje pieniężne nie tylko za celowe podpalenie, ale także nieostrożne posługiwanie się ogniem i pozostawienie go bez nadzoru oraz wzniecenie ognia przez zwierzęta (Wiliam 80-82; Jenkins, The Law of Hywel Dda 169-171).

\section{TERMINOLOGIA ZOBOWIĄZAŃ DELIKTOWYCH I UMOWNYCH}

Przejdźmy teraz do prawa zobowiązań, w pierwszej kolejności wynikających z deliktów, a w dalszej z umów. Słownictwo z zakresu zobowiązań deliktowych obejmuje następujące terminy:

- camlwrw (nawiązka za oszczerstwo męża lub opuszczenie małżeńskiego łoża) $)^{22}$,

\footnotetext{
${ }^{22}$ Gwoli wyjaśnienia, camlwrw nie było wyłącznie terminem prawa małżeńskiego. Karę finansową camlwrw nakładano na sprawcę niektórych przewinień określonych w prawie. Poborcą camlwrw, podobnie jak dirwy, był władca. Dirwy wynosiła 12 kine (krów). Camlwrw z kolei 3 kine. Obecnie dirwy oznacza grzywnę, np. dirwy parcio - grzywna za parkowanie w niedozwolonym miejscu (camlwrw/dirwy, GPC Online).
} 
- galanas (główszczyzna, opłata uiszczana przez sprawcę mężobójstwa i jego krewnych rodzinie ofiary),

- gowyn (nawiązka należna żonie za zdradę męża),

- sarhaed (naruszenie nietykalności cielesnej, obraza, krzywda, zniewaga, nawiązka),

- wynebwerth (potwarz, potwarne, kalumnia).

W prawie walijskim rzeczownik sarhaed występuje w znaczeniu zamierzonego czynu polegającego zarówno na naruszeniu nietykalności cielesnej, np. przez zranienie, pobicie czy szturchnięcie, jak i znieważeniu. Termin sarhaed opisywał również nawiązkę płaconą przez sprawcę osobie pokrzywdzonej. Wysokość sarhaed uzależniona była od pozycji społecznej i zajmowanego stanowiska pokrzywdzonego. Król, rzecz jasna, mógł liczyć na największe odszkodowanie. W przypadku kobiet sarhaed wyliczano odpowiednio do stanu męża lub brata. Sarhaed kobiet zamężnych wynosiła trzecią część sarhaed męża. Sarhaed panien szacowano na połowę sarhaed brata (Wiliam 25; Jenkins, The Law of Hywel Dda 47). Beneficjentem sarhaed był zwykle męski krewny pokrzywdzonej lub jej mąż. Kobieta otrzymywała sarhaed także od męża, gdy ten dopuścił się przemocy domowej. Prawo pozwalało na fizyczne karanie żony jedynie w trzech przypadkach takich, jak nieuzasadnione wyzbycie się ruchomości ze wspólnego majątku, zdrada i obraza męża. Przekroczenie granic określonych przez prawo skutkowało roszczeniem o wypłatę sarhaed (Wiliam 28-29; Jenkins, The Law of Hywel Dda 52-53).

Terminem zbliżonym do sarhaed jest wynebwerth. Wyraz ten powstał z połączenia rzeczowników wyneb (twarz) i gwerth (wartość). Ekwiwalentami wynebwerth $\mathrm{w}$ polskim języku prawnym doby średniowiecza są potwarz i potwarne. W pierwszym znaczeniu wynebwerth (potwarz) jest desygnatem obrazy, oszczerstwa, zniesławienia. Sprawca deliktu płacił ofierze specjalną nawiązkę zwaną wynebwerth (potwarne). Łatwo zauważyć, że w prawie walijskim i polskim omawiane terminy budzą skojarzenia $\mathrm{z}$ twarzą, licem, które było synonimem godności osoby (wynebwerth, GPC Online).

Termin galanas jest odpowiednikiem polskiej główszczyzny, odszkodowania płaconego przez sprawcę i jego krewnych rodzinie ofiary. Galanas stanowiła trzykrotną wartość sarhaed w zależności od stanu osoby zmarłej. Galanas kobiet opiewała na połowę galanas brata, niezależnie od stanu cywilnego (Wiliam 25; Jenkins, The Law of Hywel Dda 47). Cyfraith Hywel otaczało opieką prawną dzieci poczęte, nienarodzone, penalizując wszelkiego 
rodzaju akty przemocy zadane kobiecie brzemiennej. Zgodnie z jednym z zapisów śmierć nasciturusa ${ }^{23}$ dawała podstawę do wypłaty galanas $\mathrm{w}$ wysokości odpowiedniej do zaawansowania ciąży (Wiliam 65; Jenkins, The Law of Hywel Dda 129-130).

W Cyfraith Hywel znajdujemy przepisy regulujące wzajemne stosunki między małżonkami. Kobieta miała obowiązek posłuszeństwa i szacunku wobec męża, co odzwierciedla termin camlwrw. Pod camlwrw kryła się nawiązka za obrazę męża. Według Llyfr Blegywryd mąż mógł żądać camlwrw także w sytuacji bezpodstawnego odejścia kobiety od wspólnego łoża, co dosłownie oznaczało odmowę współżycia. Prawo nakładało również nakaz zadośćuczynienia zniewagi żony, jeśli doszło do aktu zdrady poprzez nawiązkę zwaną gowyn (Jenkins, The Law of Hywel Dda 53).

Specjalne regulacje dotyczyły czynu polegającego na obcowaniu z kobietą wbrew jej woli. $\mathrm{Na}$ sprawcę gwałtu nakładano grzywnę dirwy zasilającą skarbiec królewski i amobr uiszczane arglwyddowi. Jeśli ofiara była panną, gwałciciel dodatkowo płacił cowyll, agweddi, wynebwerth i dilysrwydd. Według Geiriadur Prifysgol Cymru dilysrwydd w podstawowym znaczeniu definiuje się jako zgodność, autentyczność, gwarancję i rękojmię (llythyr dilysrwydd - list potwierdzający, uwierzytelniający, certyfikat) (dilysrwydd, GPC Online). W odniesieniu do Cyfraith Hywel rzeczownik ten konotuje nienaruszalność kobiecego ciała i nawiązkę za jej pogwałcenie. Gwałt na kobiecie zamężnej karano sarhaed w wysokości wyższej o połowę (Wiliam 28; Jenkins, The Law of Hywel Dda 51-52).

Kolejna grupa walijskiego słownictwa prawnego okresu średniowiecza obejmuje terminologię z zakresu prawa umów. W Cyfraith Hywel zobowiązania umowne zaciągano na trzy sposoby:

- amod (umowa, kontrakt),

- briduw (uroczyste przyrzeczenie spełnienia zobowiązania wraz z przywołaniem Boga na gwaranta),

- machni (umowa poręczenia, poręka).

Specjalnym rodzajem poręki było gorfodogaeth (poręczenie za sprawcę czynu zabronionego).

\footnotetext{
${ }^{23}$ Nasciturus jest terminem pochodzącym z prawa rzymskiego, który oznacza płód w łonie matki, dziecko poczęte, ale jeszcze nienarodzone, dziecko mające się narodzić. Rzymianie przyznawali nasciturusowi specjalną ochronę prawną, m.in. możliwość dokonywania pewnych rozporządzeń majątkowych na jego rzecz, które wywoływały skutek ex tunc pod warunkiem, że dziecko przyszło na świat żywe (Rozwadowski 104).
} 
Polskim ekwiwalentem umowy w średniowiecznym prawie walijskim jest termin amod. Przesłankami stanowiącymi o ważności amod była wymiana składanych obietnic przez umawiające się strony, zwane w języku walijskim odpowiednio hawlwr (wierzyciel) i cynnogn (dłużnik), w obecności świadków (amodwyr), utwierdzona uściskiem rąk. Zobowiązanie powstawało również $\mathrm{w}$ procedurze machni. Warunkiem koniecznym do skutecznego zawarcia machni było umocnienie umowy osobą trzecią zwaną mach (ręczyciel, rękojmia), który, w przeciwieństwie do amodwyr, dawał gwarancję spełnienia zobowiązania (Wiliam 32-41; Jenkins, The Law of Hywel Dda 63-80; Stacey, The Road to Judgment 141-178). Jak podaje R.C. Stacey, instytucja machni przeszła stopniową ewolucję. W dawnym prawie walijskim mach pełnił głównie rolę świadka transakcji. W razie zwłoki w realizacji umowy, mach był obowiązany zastosować wszelkie dostępne środki przymusu, z siłą fizyczną włącznie, względem dłużnika zmierzające do spełnienia zobowiązania zgodnie z treścią umowy. Bierność macha narażała go na utratę czci i honoru. Około XIII wieku mach nie tylko ręczył za dłużnika dobrym imieniem, ale ponosił odpowiedzialność finansową za niewykonanie zobowiązania (Stacey, „The Archaic Core of Llyfr Iorwerth” 15-46 i The Road to Judgment 141-150). Briduw pochodzi od wyrazów bri (godność, honor, siła) i Duw (Bóg). Był to rodzaj zobowiązania zawiązywanego poprzez wymianę obietnic i uścisk rąk z przywołaniem Boga na świadka i gwaranta. W przypadku niespełnienia zobowiązania, dłużnika dotykały reperkusje natury religijnej egzekwowane przez kościół i króla takie, jak zakaz przyjmowania święconej wody i chleba, gniew boży czy ekskomunika (Wiliam 41-42; Jenkins, The Law of Hywel Dda 78-79; Pryce, Native Law and the Church in Medieval Wales 53-65; Stacey, The Road to Judgment 199-221). Gorfodogaeth odnosiło się do poręczenia stawiennictwa w sądzie sprawcy czynu zabronionego. Gorfodog składał porękę, że sprawca nie będzie uchylał się od wymiaru sprawiedliwości, stawi się na rokach sądowych, podda karze oraz wypłaci odszkodowanie (Jenkins, The Law of Hywel Dda 80-81; Pryce, Native Law and the Church in Medieval Wales 194; Stacey, The Road to Judgment 187).

Nasze rozważania na temat terminologii prawa umów zakończmy listą zobowiązań tego typu. Najbardziej rozpowszechnionymi kategoriami umów w średniowiecznej Walii były (Ellis 24-36; Watkin 64):

- adnau (umowa przechowania),

- benffyg (umowa użyczenia),

- cyfnewid (umowa kupna-sprzedaży), 
- echwyn (umowa pożyczki),

- llog (umowa dzierżawy),

- rhodd (umowa darowizny).

\section{TERMINOLOGIA PRAWA RZECZOWEGO I SPADKOWEGO}

Do najważniejszych terminów walijskiego prawa rzeczowego i spadkowego należały:

- cyfran (zasada prawa spadkowego nakazująca równy podział ziemi pomiędzy wszystkich spadkobierców płci męskiej),

- daered (zapis na rzecz kościoła dokonywany przez testatora na łożu śmierci),

- ebediw (opłata po śmierci wasala należna zwierzchnikowi),

- gwarchadw (posiadanie),

- marwdy (kaduk, puścizna, majątek ruchomy stanowiący przepadek na rzecz skarbca królewskiego w przypadku dziedziczenia bezpotomnego i beztestamentowego),

- priodawr (właściciel),

- priodolder (własność).

Prawo walijskie odróżniało posiadanie od własności. Terminem, który określał fakt dzierżenia rzeczy, był gwarchadw. Pierwsza osoba, która objęła grunt $\mathrm{w}$ posiadanie nazywała się gîw $d y f o d$ (osadnik, zasiedzca; literalnie przekładając, ten, który właśnie przybył, przyjechał od $g \hat{w} r$ - mężczyzna i $d y f o d$ - przybyły, przyjezdny). Własność opisywano za pomocą terminu priodolder. Gwarchadw przekształcało się w priodolder wówczas, gdy nieruchomość pozostawała nieprzerwanie w spokojnym posiadaniu tych samych osób (dawność, preskrypcja) przez cztery pokolenia (Watkin 61-62). Opróżnienie gruntu przez właścicieli (priodorion) dawało podstawę do jego zasiedzenia przez innych osadników w takim samym trybie. Ostatni członek rodziny pierwotnych właścicieli należący do dziewiątego pokolenia (tzw. dziewiąty) korzystał ze specjalnego przywileju zwanego Disabad uwch Annwfn. Miał on bowiem prawo domagać się od nowych właścicieli udziału w rzeczonym gruncie, powołując się na wygasłą priodolder swych przodków (Wiliam 55-56; Jenkins, The Law of Hywel Dda 104). Disabad w języku polskim to krzyk, jęk. Annwfn, występujący także pod nazwą Annwn, oznacza z kolei przepaść, otchłań, czeluść, miejsce o dużej głębokości. Przekładając literalnie na język polski, cały zwrot brzmi „krzyk nad otchłanią”. Annwfn było także nazwą 
zaświatów, mitologicznej krainy bytowania bogów i bóstw (disabad uwch Annwfn, GPC Online). Wyraz annwfn pochodzi prawdopodobnie od $d w f n$ (głęboki, świat) i przedrostka an oznaczającego negację (annwfn, GPC Online; Koch 75; Heinz, „Afterlife and Celtic Concepts of the Otherworld” 49). Annwfn było zlokalizowane w wielu miejscach, np. jaskiniach, rzekach, jeziorach, głębinach, górach czy klifach. Zwykły śmiertelnik mógł podróżować między światem ziemskim, w którym przyszło mu wieść życie, a zaświatami. Zdarzało się, że istoty z Annwfn nawiedzały ludzki padół, by ingerować w bieżące sprawy jego mieszkańców. Z Annwfn kojarzono także określone gatunki zwierząt, m.in. psy, konie, świnie, ryby, sowy. Tej niezwykłej krainie przypisywano określoną kolorystykę, najczęściej czerwień i biel (Heinz, „Afterlife and Celtic Concepts of the Otherworld" 48-50; Koch 75; Monaghan 20$)^{24}$. Wracając do rozważań na temat prawa walijskiego, pojęcie Disabad uwch Annwfn stanowiło reminiscencję wiary w moc sił nadprzyrodzonych.

Prawo cyfran (od cyfran - dział, część, porcja) regulowało sukcesję ziemi. W myśl cyfran po śmierci spadkodawcy grunt (gwely - dosłownie łoże) przechodził na wszystkich męskich prawych i nieprawych potomków lub ich zstępnych w równych częściach. Podziału na schedy dokonywał najmłodszy syn. Zasady dziedziczenia ziemi w prawie walijskim stały w wyraźnej kontrze do reguły starszeństwa obowiązującej w Anglii. Dobra takie jak młyny, łowiska, pastwiska stanowiły w Walii, według terminologii staropolskiego prawa polskiego, niedział rodzinny, co oznaczało, że były objęte własnością pospólnej ręki (Watkin 58-59).

Popularnym zwyczajem w Walii było dokonywanie rozporządzeń testamentowych majątku ruchomego na rzecz kościoła zwanych daered, zwykle w obecności duchownego. Według przepisów prawnych regulujących zasady dziedziczenia testamentowego do spadku mogli zostać powołani żona i męscy descendenci. Spadkobiercom przypadała połowa spadku po odjęciu długów i daered (Pryce, Native Law and the Church in Medieval Wales 118-123). Nagły zgon bezpotomnego spadkodawcy powodował przejście ruchomego spadku na króla. Mienie ruchome należące do zmarłego nazywano marwdy, dosłownie dom nieboszczyka (od marw - martwy, zmarły, th-dom). Obecnie

\footnotetext{
${ }^{24}$ Obraz zaświatów zmienił się wraz z kolonizacją Walii przez Anglo-Normanów. Reprezentacji zaświatów w średniowiecznej literaturze walijskiej w kontekście przeobrażeń społecznych i kulturowych poświęca uwagę Asmus w opracowaniu „Changing Celtic Concepts of the Otherworld and Afterlife”. Ciekawym projektem badawczym jest komparatystyka wizji zaświatów w średniowiecznej literaturze walijskiej i polskiej. Zob. Sokolski, Szczepanik.
} 
marwdy oznacza kostnicę, miejsce przechowywania zwłok, a także rzeźnię (Pryce, Native Law and the Church in Medieval Wales 113-118; marwdy, GPC Online). Polskim ekwiwalentem marwdy jest puścizna, kaduk. Po śmierci wasala zwierzchnik nabywał prawo do ebediw, specjalnej opłaty składanej zwykle w postaci zwierząt (psów, koni), broni lub monet.

\section{TERMINOLOGIA PRAWA PROCESOWEGO}

Zakończmy analizę terminologii prawnej Cyfraith Hywel słownictwem procesowym. Do podstawowych pojęć walijskiego prawa sądowego należą takie terminy, jak:

- ach ac edryf (powództwo/skarga składana przeciwko pozwanemu spokrewnionemu z powodem o bezprawne pozbawienie posiadania),

- amddiffynnwr (pozwany),

- canllaw (pełnomocnik upoważniony do podejmowania czynności w imieniu stron),

- ceidwad (świadek z doświadczenia),

- cyngaws (mówca, pełnomocnik reprezentujący strony w postępowaniu sądowym),

- cynghawsedd (wymiana argumentów, spór, postępowanie),

- dadannudd/dadanhudd (powództwo/skarga składana przeciwko pozwanemu o bezprawne pozbawienie posiadania gruntu należącego do przodka powoda),

- gwybyddiad (świadek naoczny, świadek ze słyszenia),

- haulur (powód),

- rhaith (przysięga),

- tafodiog (świadek, którego zeznania nie podlegały weryfikacji w trakcie postępowania sądowego),

- tyst (świadek toczącego się postępowania),

- ynad (sędzia).

Według opisu modelowego postępowania w sprawach o ziemię przedstawionego w Llyfr Iorwerth spór toczył się przed zespołem złożonym z sędziego lub sędziów (ynad/ynaid). Na ławie zasiadał także król w towarzystwie duchownego, hynafiaid (starszyzny) i gwrda (wielmoży). Haulur (powód) występował z roszczeniem przeciwko amddiffynnwr (pozwanemu) (Wiliam 45-46; Jenkins, The Law of Hywel Dda 83-98). Proces rozpoczynat się od cynghawsedd, czynności polegającej na wymianie argumentów przez 
strony (Charles-Edwards, „Cynghawsedd: Counting and Pleading in Medieval Welsh Law” 188-198; Stacey, „Learning to Plead in Medieval Welsh Law" 107-124). Strony korzystały z pomocy profesjonalistów, cyngawsa i canllawa (Jenkins, „Towards the Jury in Medieval Wales” 40; Watkin 72; Smith, „Judgement under the Law of Wales” 65-66). Redaktorzy Cyfraith Hywel nie precyzują, jaka była funkcja obu pełnomocników. D. Jenkins w przekładzie zbioru na język angielski zostawia te terminy w wersji oryginalnej (The Law of Hywel Dda 84-86). Specyfikę obu zawodów wyjaśnia zwięźle T.G. Watkin, przekładając cyngawsa na pleader/advocate a cynllawa na guider/attorney. Cyngaws, wedle Watkina, reprezentował strony w toczącym się postępowaniu i prowadził w ich imieniu wywód. Posiadał on wiedzę z zakresu retoryki prawniczej i genealogii. Canllaw był pełnomocnikiem stron, który nie bronił ich bezpośrednio w trakcie rozprawy. Jego rola polegała na podejmowaniu określonych czynności w imieniu i na rzecz stron (Watkin 72). Pewne światło na rolę canllawa w procesie sądowym rzuca znaczenie tego wyrazu w języku ogólnym. Canllaw oznacza poręcz, balustradę oraz przewodnika (canllaw, GPC Online). Można zatem domniemywać, że canllaw udzielał wsparcia merytorycznego i technicznego dla cyngawsa w procedowanej sprawie.

Podstawowym sposobem dochodzenia swoich racji było powoływanie się na zeznania świadków, głównie rodziny, sąsiadów i przysięgi współprzysiężników. W Walii nie stosowano ordalii wody, żelaza czy pojedynku powszechnie praktykowanych w większości państw epoki średniowiecza. Świadków dzielono na trzy kategorie: tystion, ceidwaid i gwybyddiaid. Tyst (ten, który poświadcza) oznaczał osobę, która składała relację z przebiegu postępowania sądowego i czynności dokonanych w jego trakcie przez strony procesowe. Tyst był swoistego rodzaju obserwatorem toczącego się postępowania. Ceidwad ma w języku walijskim podwójne znaczenie. Termin ten konotuje po pierwsze powiernika, opiekuna, kuratora, kustosza, a po drugie świadka (cadw - zachować, przestrzegać) (ceidwad, GPC Online). W kontekście średniowiecznej terminologii procesowej wyrazu ceidwad używano na opis świadka posiadającego wiedzę na temat określonych faktów, np. stanu prawnego, granic czy pochodzenia spornej rzeczy. Gwybyddiad (dosłownie ten, który wie od czasownika gwybod - wiedzieć, znać ${ }^{25}$ ) zeznawał na okoliczność tego, co zasłyszał lub zobaczył na miejscu zdarzenia, np. bezprawnego zajęcia gruntu (Jenkins, „Towards the Jury in Medieval Wales” 27;

${ }^{25}$ Gwybyddiad oznacza także wiedzę, umiejętności (gwybyddiad, GPC Online). 
Watkin 74; Smith „Judgement under the Law of Wales” 66). Określonym świadkom przyznawano status tafodogion. Tafodiog w literalnym brzmieniu znaczy ten, który mówi (tafod - język) (tafodiog, GPC Online). Zeznania tafodioga były wiążące dla sądu, nie podlegały obaleniu i nie wymagały potwierdzenia przez współprzysiężników. Prawo przewidywało dziewięć kategorii takich świadków (Y Naw Tafodiog). Przykładem tafodioga był sprawca kradzieży składający zeznania przed egzekucją (Wiliam 32-33; Jenkins, The Law of Hywel Dda 61-62).

Głównym środkiem dowodowym w prawie walijskim była przysięga. W Cyfraith Hywel dominuje przysięganie na relikwie, np. w trakcie zaprzeczania ojcostwa czy składania przez kobietę zeznań obciążających mężczyznę o gwałt. Omawiając terminologię prawa walijskiego, należy wymienić dwie specjalne procedury zwane diofrydog i dogn fanag. W ramach diofrydog przysięgę składali trzej mężczyźni pod rygorem utraty takich przywilejów, jak jazda konna, obcowanie z kobietą, noszenie lnianej bielizny czy spożywanie mięsa (Pryce, Native Law and the Church in Medieval Wales 44-47). Dogn fanag polegało na informowaniu oficera noszącego nazwę rhaglaw, reprezentanta króla w terenie, o fakcie popełnienia kradzieży, a następnie poparciu zawiadomienia przysięgą w obecności duchownego (Pryce, Native Law and the Church in Medieval Wales 48-49).

Prawu Cyfraith Hywel nieznane były ryty procesowe (writs) ${ }^{26}$. Ryty zostały dopiero wprowadzone przez Ustawę z Rhuddlan z 1284 roku. Osoba wyzuta z posiadania nieruchomości dochodziła swych praw, korzystając z innych form, m.in. dadannudd/dadanhudd. Dadannudd oznacza dosłownie wzniecenie, odkrycie ognia nad rodzinnym paleniskiem (dadannudd, GPC Online; Wiliam 55; Jenkins, The Law of Hywel Dda 101-104). Termin ten uwypukla funkcję ognia jako bezpośredniego źródła ciepła i światła w średniowiecznym domostwie. Pod pojęciem dadannudd kryła się skarga, wzorowana, jak twierdzi T.G. Watkin, na angielskiej asyzie mort d'ancestor. $\mathrm{W}$ dadannudd powód podnosił przeciwko pozwanemu zarzut bezprawnego wyzucia z władztwa nad gruntem po śmierci przodka w linii prostej (ojca lub dziadka). Innymi słowy, osoba czyniąca użytek z dadannudd domagała się restytucji należnej schedy spadkowej, którą zgodnie z prawem nabyła od spadkodawcy. Powód pozbawiony władania mógł także powołać się na for-

\footnotetext{
${ }^{26}$ Angielskie writs były środkiem procesowym wydawanym przez kancelarię królewską w celu zainicjowania postępowania sądowego przez powoda. Na temat rytów istnieje bogata literatura przedmiotu, głównie anglojęzyczna. Po polsku o rytach pisał m.in. Halberda 94-110.
} 
mułę ach ac edryf (dosłownie pokrewieństwo i pochodzenie), która inicjowała postępowanie przeciwko władającemu gruntem pozwanemu. Warunkiem wszczęcia postępowania w oparciu o cwyn ach ac edryf było istnienie pokrewieństwa pomiędzy przeciwnikami procesowymi (Watkin 93-94).

W średniowiecznym prawie walijskim nie istniała apelacja rozumiana jako zaskarżenie wyroku do sądu wyższej instancji. Cyfraith Hywel przewidywało natomiast procedurę analogiczną do polskiej nagany sędziego na wypadek kwestionowania werdyktu przez powoda lub pozwanego. Naganę, znaną w języku polskim także jako łajanie, ruszenie i naganianie, wszczynano po złożeniu przez zarówno sędziego jak i stronę podnoszącą zarzut wadliwości wyroku zabezpieczenia, według terminologii prawa polskiego koczu. Sędzia, który nie zdołał obronić i odpowiednio uzasadnić zgodności wydanego przez siebie wyroku z obowiązującymi przepisami był karany utratą prawa do wykonywania zawodu oraz grzywną opiewającą na wartość języka wpłacaną do skarbca królewskiego. Jeśli natomiast nie stwierdzono przesłanek rewizji wyroku i tym samym oddalono zarzut strony, która występowała z roszczeniem jego unieważnienia, sędzi przysługiwała sarhaed (Wiliam 8-9; Jenkins, The Law of Hywel Dda 17; Smith, „Ynad Llys, Brawdwr Llys, Iudex Curie” 94-115; Watkin 70-71). Oba rozwiązania prawne łączy nie tylko wymóg poparcia żądania koczem, w prawie walijskim podwójnym, ale także konsekwencje nagany dla sędziego. Skutecznie naganiony sędzia w polskim i walijskim prawie tracił cześć i godność, wyrazem czego było odsunięcie od orzekania i nałożenie kary finansowej w wysokości zależnej od jego pozycji społecznej (Rafacz, Dawne prawo sadowe polskie w zarysie 186-190).

\section{WNIOSKI KOŃCOWE}

Zadaniem badawczym postawionym $\mathrm{w}$ niniejszej pracy było określenie paralelizmów i rozbieżności między terminologią walijską a polską. Dla wielu terminów prawa walijskiego można odnaleźć odpowiedniki w zasobie leksykalnym prawa staropolskiego. Podobieństwa są dostrzegalne w sferze prawa dworskiego i małżeńskiego. Zarówno na dworze walijskim, jak i polskim służyła wyspecjalizowana kadra zajmująca się służbą przy stole, w komnacie, u wrót dworskich, w kuchni i stajni dworskiej. Zawarcie małżeństwa w dawnej Walii i Polsce było celebrowane poprzez wymianę różnych apanaży przez krewnych panny i jej przyszłego męża. Kolejną cechą wspólną obu systemów prawnych była zróżnicowana terminologia dotycząca 
odszkodowania. Umowy zawierano w podobny sposób poprzez podanie ręki, w obecności świadka lub gwaranta.

Niektóre terminy prawa walijskiego okazały się nieprzekładalne z uwagi na brak ekwiwalentnych regulacji i rozwiązań prawnych oraz odmiennych tradycji. Do tej grupy należą nazwy pewnych dystynkcji i godności dworskich (bardd teulu, pencerdd, troediog), zawody prawnicze (brawdwr, ynad, dosbarthwr), pełnomocnicy stron procesowych (cyngaws, canllaw). Jaskrawym przykładem braku ekwiwalencji są terminy briduw, dadannudd, disabad uwch Annwfn. Briduw nawiązuje do rytuału odwoływania się do bogów i bóstw w sprawach życia codziennego, także w trakcie dokonywania czynności prawnych. Dadannudd akcentuje specjalne znaczenie ognia. Disabad uwch Annwfn jest reliktem wierzeń w pozaziemską krainę Annwfn.

Nie sposób oddać osobliwości terminologii prawa walijskiego, problemów tłumaczeniowych, jakie z nich wypływają i kunsztu myśli prawniczej średniowiecznych jurystów na kilkudziesięciu stronach. Szczegółowe studium walijskiego słownictwa prawnego w kontekście komparatystycznym walijsko-polskim, zwłaszcza $\mathrm{w}$ aspekcie recepcji literatury walijskiej $\mathrm{w}$ Polsce stanowi $\mathrm{z}$ pewnością temat na oddzielną monografię. Wypada mieć nadzieję, że przedstawiona $\mathrm{w}$ artykule wybrana terminologia prawna jest wstępem do dalszych badań na gruncie polskiej lingwistyki, przekładoznawstwa i historii prawa.

\section{BIBLIOGRAFIA}

\section{ŹRÓDŁA}

Biblia. Pismo Święte Starego i Nowego Testamentu. Brytyjskie i Zagraniczne Towarzystwo Biblijne, 1990.

Emanuel, Hywel David, ed. The Latin Texts of the Welsh Laws. University of Wales Press, 1967.

Geiriadur Prifysgol Cymru: A Dictionary of the Welsh Language. University of Wales Centre for Advanced Welsh \& Celtic Studies, 2014, geiriadur.ac.uk. Dostęp 1.12.2020.

Jenkins, Dafydd, ed./trans. The Law of Hywel Dda: Law Texts from Medieval Wales. Gomer Press, 1990.

Owen, Aneurin, ed./trans. Ancient Laws and Institutes of Wales. G.E. Eyre and A. Spottiswoode, 1841.

Richards, Melville, ed./trans. The Laws of Hywel Dda. University Press, 1954.

Roberts, Sara Elin, ed./trans. The Legal Triads of Medieval Wales. University of Wales Press, 2011.

Roberts, Sara Elin, ed./trans. Llawysgrif Pomffred: an Edition and Study of Peniarth MS $259 B$. Brill, 2011.

Wade-Evans, Arthur, ed./trans. Welsh Medieval Law. Clarendon Press, 1909. 
Wiliam, Aled Rhys, ed. Llyfr Iorwerth: A Critical Text of the Venedotian Code of Medieval Welsh Law. University of Wales Press, 1960.

Williams, Gwyn, trans. Welsh Poems: Sixth Century to 1600. Faber and Faber, 1973.

\section{LITERATURA PRZEDMIOTOWA}

Asmus, Sabine. „Changing Celtic concepts of the otherworld and afterlife”, www.academia.edu/ 31603072/Changing_Celtic_concepts_of_the_Otherworld_and_Afterlife. Dostęp 2.12.2020.

Bardach, Juliusz. Historia państwa i prawa Polski. Tom 1: Do połowy XV wieku, Państwowe Wydawnictwo Naukowe, 1965.

Bromwich, Rachel, ed. Trioedd Ynys Prydein: The Triads of the Island of Britain. University of Wales Press, 2014.

Bromwich, Rachel. „The Triads of the Horses”. The Horse in Celtic Culture: Medieval Welsh Perspectives, edited by Sioned Davies, Nerys Ann Jones, University of Wales Press, 1997, ss. 102-120.

Buczek-Zawiła, Anita. „Najwcześniejsza literatura walijska”. Wielka historia literatury anglojęzycznej. Tom I: Literatura wczesnośredniowieczna do roku 1066, red. Anastazja Oleśkiewicz, Wydawnictwo Naukowe Uniwersytetu Pedagogicznego, 2012, ss. 361-386.

Carey, John. „Legendary History of the Celtic Peoples”. Celtic Culture: A Historical Encyclopedia. Volume III, edited by John T. Koch, ABC-CLIO, 2006, ss. 1130-1131.

Charles-Edwards, Thomas M. „Naw Kynywedi Teithiauc”. The Welsh Law of Women: Studies Presented to Professor Daniel A. Binchy on His Eightieth Birthday, edited by Dafydd Jenkins, Morfydd E. Owen, University of Wales Press, 1980, ss. 23-39.

Charles-Edwards, Thomas M. „Cynghawsedd: Counting and Pleading in Medieval Welsh Law”. Bulletin of the Board of Celtic Studies, nr 33, 1986, ss. 188-198.

Charles-Edwards, Thomas M, i Paul Russell, ed. Tair Colofn Cyfraith: The Three Columns of Law in Medieval Wales: Homicide, Theft and Fire. The Welsh Legal History Society, 2007.

Davies, Robert Rees. „The Status of Women and the Practice of Marriage in Late-medieval Wales". The Welsh Law of Women: Studies Presented to Professor Daniel A. Binchy on His Eightieth Birthday, edited by Dafydd Jenkins, Morfydd E. Owen, University of Wales Press, 1980, ss. 93-114.

Davies, Robert Rees. „The Administration of Law in Medieval Wales: The Role of the Ynad Cwmwd (judex patrie)". Lawyers and Laymen: Studies in the History of Law Presented to Professor Dafydd Jenkins on His Seventy-fifth Birthday, Gwyl Ddewi 1986, edited by Douglas Walters, Thomas M. Charles-Edwards, Morfydd E. Owen, University of Wales Press, 1986, ss. 258-273.

Davies, Wendy. „Adding Insult to Injury: Power, Property and Immunities in Early Medieval Wales". Property and Power in the Early Middle Ages, edited by Wendy Davies, Paul Fouracre, Cambridge University Press, 1995, ss. 137-164.

Davies, Sioned. „Storytelling in Medieval Wales”. Oral Tradition, t. 7, nr 2, 1992, ss. 231-257.

Elias, Gwenno Angharad, i Owen Morfydd. „Lawmen and Lawbooks”. Canmlwyddiant, Cyfraith a Chymreictod: A Celebration of the Life and Work of Dafydd Jenkins 1911-2012, edited by Noel S.B. Cox, Thomas Glyn Watkin, The Welsh Legal History Society, 2013, ss. 106-150.

Ellis, Thomas Peter. Welsh Tribal Law and Custom in the Middle Ages. Vol. 2, Clarendon Press, 1926.

Gloger, Zygmunt. Encyklopedia staropolska. Wiedza Powszechna, 1958. 
Góralski, Zbigniew. Urzędy i godności w dawnej Polsce. Ludowa Spółdzielnia Wydawnicza, 1988.

Halberda, Jan. Historia zobowiązań quasi-kontraktowych w common law. Księgarnia Akademicka, 2012.

Heinz, Sabine. „Walisisch”. Variationstypologie. Variation Typology. Ein sprachtypologisches Handbuch der europäischen Sprachen in Geschichte und Gegenwart: A Typological Handbook of European Language Past and Present, edited by Thorsten Roelcke, Walter de Gruyter, 2003, ss. 277-307.

Heinz, Sabine. Welsh Dictionaries in the Twentieth Century: A Critical Analysis. Lincom Europa, 2003.

Heinz, Sabine. „Afterlife and Celtic Concepts of the Otherworld”. Thise Stories Beren Witnesse: The Landscape of the Afterlife in Medieval and Post-medieval Imagination, edited by Liliana Sikorska, Peter Lang, 2010, ss. 43-58.

Huws, Catrin Fflur. „Law, Literature, Language and the Construction of Welsh Identity”. The Carno Poisonings and Other Essays, edited by Thomas Glyn Watkin, The Welsh Legal History Society, 2013, ss. 99-120.

Huws, Daniel. „Peniarth 28: Illustrations from a Welsh Lawbook”, www.library.wales/discover/ digital-gallery/manuscripts/the-middle-ages/laws-of-hywel-dda/daniel-huws-article-peniarth-28illustrations-from-a-welsh-lawbook. Dostęp 20.02.2020.

James, Christine. „Dafydd (Llwyd): Dosbarthwr: The Literary Culture of Some Cardiganshire Lawyers". Canmlwyddiant, Cyfraith a Chymreictod: A Celebration of the Life and Work of Dafydd Jenkins, 1911-2012, edited by Noel Cox, Thomas Glyn Watkin, The Welsh Legal History Society, 2013, ss. 154-169.

Jaworska-Biskup, Katarzyna. „The Legal Status of a Woman as Reflected in Medieval Welsh Law”. Acta Philologica, $\mathrm{nr}$ 43, 2013, ss. 21-28.

Jaworska-Biskup, Katarzyna. „Małżeństwo i rozwód w średniowiecznym prawie Hywel Dda (Cyfraith Hywel)". Czasopismo Prawno-Historyczne, t. 66, nr 2, 2014, ss. 241-253.

Jaworska-Biskup, Katarzyna. „Rozwój prawa średniowiecznej Walii do 1284 roku - perspektywa historyczna". Krakowskie Studia z Historii Państwa i Prawa, t. 11, nr 2, 2018, ss. 197-216.

Jaworska-Biskup, Katarzyna. Selected Medieval Literature from Wales, Scotland and England Reflecting Changes in Welsh and Scottish Law. Wydawnictwo Naukowe Uniwersytetu Szczecińskiego, 2018.

Jaworska-Biskup, Katarzyna. „Some Remarks on the Periodisation of Welsh Medieval Law”. Redefining the Fringes in Celtic Studies, edited by Aleksander Bednarski, Robert Looby, Peter Lang, 2019, ss. 51-65.

Jenkins, Dafydd. „Prolegomena to the Welsh Laws of Court”. The Welsh King and His Court, edited by Thomas M. Charles-Edwards, Morfydd Elizabeth Owen, Paul Russell, University of Wales Press, 2000, ss. 15-28.

Jenkins, Dafydd. „Bardd Teulu and Pencerdd”. The Welsh King and His Court, edited by Thomas M. Charles-Edwards, Morfydd Elizabeth Owen, Paul Russell, University of Wales Press, 2000, ss. $142-166$.

Jenkins, Dafydd. „Kings, Lords, and Princes: The Nomenclature of Authority in Thirteenth-century Wales". Bulletin of the Board of Celtic Studies, t. 26, 1974-1976, ss. 451-462. 
Jenkins, Dafydd. „Towards the Jury in Medieval Wales”. The Dearest Birth Right of the People of England: The Jury in the History of the Common Law, edited by John Cairns, Grant McLeod, Hart Publishing, 2002, ss. 17-46.

Jenkins, Dafydd, i Morfydd E. Owen, eds. The Welsh Law of Women: Studies Presented to Professor Daniel A. Binchy on His Eightieth Birthday, University of Wales Press, 1980.

Johnson, Lizabeth. „Amobr and Amobrwyr: The Collection of Marriage Fees and Sexual Fines in Late Medieval Wales". Transactions of the Honourable Society of the Cymmrodorion, t. 18, 2012, ss. 10-21.

Kelly, Fergus. „Thinking in Threes: The Triad in Early Irish Literature. Sir John Rhŷs Memorial Lecture". Proceedings of the British Academy, t. 125, 2004, ss. 1-18.

Koch, John T. „Annwn/annwfn”. Celtic Culture: A Historical Encyclopedia. Vol. 1, edited by John T. Koch, ABC-CLIO, 2006, s. 75.

Koczerska, Maria. Rodzina szlachecka w Polsce późnego średniowiecza. Państwowe Wydawnictwo Naukowe, 1975.

Kutrzeba, Stanisław. Dawne polskie prawo sądowe w zarysie. Zakład Narodowy im. Ossolińskich, 1927.

Linde, M. Samuel Bogumił. Stownik języka polskiego. Lwów 1854.

Lis, Artur. Family Law of the Piast Poland. Wydawnictwo KUL, 2017.

Lizisowa, Maria. Podstawowe terminy prawne $w$ statutach staropolskich na tle slowiańskim. Studium semantyczne. Wydawnictwo Naukowe WSP, 1995.

Majewicz, Alfred, i Elżbieta Majewicz. „Literatura walijska”. Dzieje literatur europejskich. Tom III, cz. 2, Państwowe Wydawnictwo Naukowe, 1991, ss. 728-749.

McAll, Christopher. „The Normal Paradigms of a Woman's Life in the Irish and Welsh Law Texts”. The Welsh Law of Women. Studies Presented to Professor Daniel A. Binchy on His Eightieth Birthday, edited by Dafydd Jenkins, Morfydd E. Owen, University of Wales Press, 1980, ss. 7-22.

Monaghan, Patricia. „Annwn”. The Encyclopedia of Celtic Mythology and Folklore, Patricia Monaghan, Facts on File, 2004.

Owen, Morfydd E. „Medics and Medicine”. The Welsh King and His Court, edited by Thomas M. Charles-Edwards, Morfydd Elizabeth Owen, Paul Russell, University of Wales Press, 2000, ss. 116-141.

Pryce, Huw. Native Law and the Church in Medieval Wales. Oxford University Press, 1993.

Pryce, Huw. „The Household Priest (Offeiriad Teulu)”. The Welsh King and His Court, edited by Thomas M. Charles-Edwards, Morfydd Elizabeth Owen, Paul Russell, University of Wales Press, 2000, ss. 82-93.

Rafacz, Józef. Dawne prawo sq̨dowe polskie w zarysie. Zakład Narodowy im. Ossolińskich, 1936.

Rafacz, Józef. „Kradzież w prawie łęczyckiem XIV i XV wieku”. Przegląd Historyczny, t. 30, nr 1, 1932-1933, ss. 33-45.

Roberts, Sara Elin. „Plaints in Medieval Welsh Law”. The Journal of Celtic Studies, nr 4, 2004, ss. $219-261$

Roberts, Sara Elin. „Emerging from the Bushes: The Welsh Law of Women in the Legal Triads”. Literature and Society (CSANA Yearbook), edited by Sara Elin Roberts, Joseph F. Eska, 2008, ss. 58-76. 
Roberts, Sara Elin. „The Iorwerth Triads”. Tome: Studies in Medieval Celtic History and Law in Honour of Thomas Charles-Edwards, edited by Fiona Edmonds, Paul Russell, Boydell Press, 2011, ss. 155-164.

Roberts, Sara Elin. „The Welsh Legal Triads”. The Welsh Legal Triads and Other Essays, edited by Thomas Glyn Watkin, The Welsh Legal History Society, 2012, ss. 1-22.

Roberts, Sara Elin. „More Plaints in Medieval Welsh Law”. Studia Celtica, t. 48, 2014, ss. 171-199.

Rosiak, Karolina. „Rola narodowego Eisteddfodu w kultywowaniu i rozwoju poezji walijskiej”. Litteraria Copernicana, nr 2, 2019, ss. 155-165.

Rozwadowski, Władysław. „Nasciturus”. Prawo rzymskie. Słownik encyklopedyczny, red. Witold Wołodkiewicz, Wiedza Powszechna, 1986, s. 104.

Seminar Cyfraith Hywel, cyfraith-hywel.org.uk. Dostęp 2.12.2020.

Smith, Jenkyn Beverley. „Ynad Llys, Brawdwr Llys, Iudex Curie”. The Welsh King and His Court, edited by Thomas M. Charles-Edwards, Morfydd Elizabeth Owen, Paul Russell, University of Wales Press, 2000, ss. 94-115.

Smith, Jenkyn Beverley. „Judgement under the Law of Wales”. Studia Celtica, t. 39, 2005, ss. 63-103.

Sokolski, Jacek. Staropolskie zaświaty. Obraz piekła, czyśćca i nieba w renesansowej i barokowej literaturze polskiej wobec tradycji średniowiecznej. Wydawnictwo Uniwersytetu Wrocławskiego, 1994.

Stacey, Robin Chapman. „Learning to Plead in Medieval Welsh Law”. Studia Celtica, t. 38, 2004, ss. 107-124.

Stacey, Robin Chapman. Law and the Imagination in Medieval Wales. University of Pennsylvania Press, 2018.

Stacey, Robin Chapman. The Road to Judgment: From Custom to Court in Medieval Ireland and Wales. University of Pennsylvania Press, 1994.

Stacey, Robin Chapman. „The Archaic Core of Llyfr Iorwerth”. Lawyers and Laymen. Studies in the History of Law presented to Professor Dafydd Jenkins on His Seventy-fifth Birthday, Gwyl Ddewi 1986, edited by Douglas Walters, Thomas M. Charles-Edwards, Morfydd E. Owen, University of Wales Press, 1986, ss. 15-46.

Ślaski, Bolesław. Materjały do polskiego słownika prawniczego. Drukarnia Spółkowa w Kępnie, 1931.

Szczepanik, Paweł. Stowiańskie zaświaty. Wierzenia, wizje i mity. Triglav, 2018.

Watkin, Thomas Glyn. The Legal History of Wales. University of Wales Press, 2007.

Williams, Patricia, ed. Historical Texts from Medieval Wales. The Modern Humanities Research Association, 2012.

Wood, Juliette. „Welsh triads”. The Encyclopedia of Medieval Literature in Britain, ed. Sian Echard, Robert Rouse, Willey Blackwell, 2017, ss. 1896-1900.

Zajda, Aleksander. Nazwy urzędników staropolskich (do roku 1600). Wydawnictwo Naukowe Uniwersytetu Jagiellońskiego, 1970.

Zajda, Aleksander. Staropolska terminologia prawnicza (do 1500 r.). Wydawnictwo Naukowe Uniwersytetu Jagiellońskiego, 1990. 


\section{PRAWO SRRENIOWIECZNEJ WALII CYFRAITH HYWEL - PROLEGOMENA DO GLOSARIUSZA WALIJSKO-POLSKIEJ TERMINOLOGII PRAWNEJ}

\section{Streszczenie}

W artykule dokonano przeglądu wybranej terminologii prawa średniowiecznej Walii wraz z przekładem na język polski. Analizowane słownictwo podzielono na takie kategorie, jak urzędy dworskie, prawo rodzinne i małżeńskie, rzeczowe, zobowiązań, karne i postępowanie sądowe. Opracowanie stanowi przyczynek do walijsko-polskiego słownika średniowiecznej terminologii prawnej. Materiał badawczy zebrano na podstawie źródeł prawa, komentarzy i literatury przedmiotowej, zarówno polskiej, jak i obcej.

Słowa kluczowe: terminologia prawna; Walia; średniowiecze; komparatystyka walijsko-polska.

\section{CYFRAITH HYWEL - A PROLEGOMENA TO WELSH-POLISH LEGAL TERMINOLOGY}

S u m m a r y

This article presents an overview of selected legal terminology of Welsh medieval law. Welsh legal terms are appended with their Polish equivalents. The legal vocabulary pertains to the following categories: posts and professions, family and marital law, property law, the law of obligations, criminal law, and judicial proceedings. The paper aims at providing a Welsh-Polish glossary of legal terms. The material subjected to the analysis has been extracted from legal sources, commentaries and other literature.

Key words: legal terminology; Wales; Middle Ages; Welsh-Polish comparative studies. 